Tarih Kültür ve Sanat Araştırmaları Dergisi

Revue des Recherches en Histoire Culture et Art

مجلة البحوث التاريخية والثقافية والفنية
Vol. 6, No. 1, February 2017

Copyright (C) Karabuk University

http://kutaksam.karabuk.edu.tr

\title{
DOI: 10.7596/taksad.v6i1.755
}

Citation: Noghlehbari, M. (2017). Analyzing Spatial Factors in Crime-inducing Culture in Chaloos. Journal of History Culture and Art Research, 6(1), 474-488. doi:http://dx.doi.org/10.7596/taksad.v6i1.755

\section{Analyzing Spatial Factors in Crime-inducing Culture in Chaloos}

\section{Mohammad Hossein Omidi Noghlehbari ${ }^{1}$}

\begin{abstract}
Feelings of security in urban areas are one of the qualitative criteria of living space. With the rise in urbanization and increasing abnormal urban behavior, especially offenses, this issue has become of great importance. This study aims to identify and analyze the effects of spatial factors on crime-inducing culture in affluent and non-affluent neighborhoods of Chaloos. The method used in this study is analytical-descriptive and it is practical in terms of objective. In order to study and understand the status of physical-spatial structures of affluent and nonaffluent neighborhoods in Chaloos, we used field study method. Data were collected through interview, notes taking and questionnaire. The results indicate that in affluent neighborhoods, all criteria components of spatial differences are above the mean (Mean=3), but in nonaffluent neighborhoods, all components are lower than the mean. In addition, there is a significant relationship between criteria components of spatial differences and the formation of crime-inducing culture (except the diagnosis component) in the affluent and non-affluent neighborhoods.
\end{abstract}

Keywords: Urban space, Spatial differences, Crime-inducing culture, Chaloos.

\footnotetext{
1 Department of Art and Architecture, Babol Branch, Islamic Azad University, Babol, Iran. E mail: pedram131@gmail.com
} 


\section{Introduction}

With urbanization and the need to feel security in public spaces, we need to understand and explore the influential factors in this regard, as creating inconsistencies between the activities, population, and space causes urban insecurity and crime. Thus, understanding the environment and spaces and the factors that lead to insecurity and chaos are important issues that designers and urban planners in urban management should consider (Bayat, 2000). The most important theory that has been proposed is a theory known as "crime prevention through environmental design".

\section{Literature review}

In fact, from 1960 onwards, an increasing interest in studying the role of environment in delinquency and in opposite the effects of environmental conditions in preventing crime took place. Jane Jacobs was one of the pioneers of this idea. In her famous work titled The Death and Life of Great American Cities, which was published in 1961, she described urban design issue and its effect in reducing delinquency, as well as natural and ordinary care of people in the prevention of delinquency.

In 1969, Ray Jeffrey was the first one to use the term "crime prevention through urban design". He emphasized on urban planning and design of urban structures and the neighborhoods in order to control and prevent crime (see Cozens et al., 2005: 329).

In 1973, along with ideas of crime prevention, Oscar Newma introduced defensible space theory. Newman's study was a solution for the high rate of crime in US cities. He believed that a crime-resistant space provides the opportunity to reform residential urban environment.

One of the legitimate rights of citizens is to have safety while they are in the urban areas. This safety should be considered from two aspects of physiological safety and psychological safety. However, some unplanned and illegal constructions in cities have caused urban spaces completely defenseless against delinquency and crime (Dickens, 2004).

Many experts believe that symbols and signs are other variables in the perspectives of municipal authorities as important factors to distinguish different parts of the city. And so people, especially strangers, and newcomers feel safe through the environment by and find their own way (Lynch, 1967: 92). Visualizing the city through a host of signs has a symbolic role in history, information, and guidance or regulation or is sign of two or more types of 
information. (Pierre Maurer et al. 1994: 269). "Basically, using urban space is related to information and data that are provided by the symbols in the surrounding areas and the amount in which information can be received by pedestrians optimize symptoms (or even audio) that transfer environmental content data" (Salingaros, 1999: 12).

Important theories on crime and safety are provided in Table 1:

Table 1: Four well-known theories related to crime and violence in urban spaces

\begin{tabular}{|c|c|c|c|}
\hline & $\begin{array}{l}\text { Space Control / } \\
\text { Governance }\end{array}$ & Supervision & Activity \\
\hline Jane Jacobs & $\begin{array}{l}\text { A clear distinction } \\
\text { between the public and } \\
\text { private spheres. }\end{array}$ & $\begin{array}{l}\text { Watchers from the } \\
\text { natural owners, } \\
\text { residents and users that } \\
\text { can use a variety of } \\
\text { activities and measures } \\
\text { that will attract people } \\
\text { should be strengthened. }\end{array}$ & $\begin{array}{l}\text { Activities surrounding } \\
\text { streets must provide } \\
\text { continuous followers, } \\
\text { to strengthen } \\
\text { monitoring. }\end{array}$ \\
\hline Oscar Newman & $\begin{array}{l}\text { Physical environment } \\
\text { should have } \\
\text { characteristics such as } \\
\text { symbolic mechanisms, } \\
\text { borders and } \\
\text { hierarchical of private } \\
\text { to public sectors to } \\
\text { understand the } \\
\text { different zones. }\end{array}$ & $\begin{array}{l}\text { Creating physical- } \\
\text { surveillance capacity in } \\
\text { space to make } \\
\text { controlling } \\
\text { opportunities for } \\
\text { residents and other } \\
\text { institutions possible. }\end{array}$ & $\begin{array}{l}\text { Opposed the idea that } \\
\text { more presence of } \\
\text { activities especially } \\
\text { business reduces crime. }\end{array}$ \\
\hline $\begin{array}{l}\text { Institute of Crime } \\
\text { Prevention (CPTED) }\end{array}$ & $\begin{array}{l}\text { Natural access control } \\
\text { to reduce crime } \\
\text { opportunities, the use } \\
\text { of physical restriction. }\end{array}$ & $\begin{array}{l}\text { Natural surveillance as } \\
\text { a normal result of using } \\
\text { property }\end{array}$ & $\begin{array}{l}\text { Emphasis on reduction } \\
\text { of activity through } \\
\text { movement and, } \\
\text { consequently, } \\
\text { reduction in activity } \\
\text { level. }\end{array}$ \\
\hline Bill Hiller & $\begin{array}{l}\text { Creating an integrated } \\
\text { environment that }\end{array}$ & $\begin{array}{l}\text { Monitoring by the } \\
\text { people who move in }\end{array}$ & $\begin{array}{l}\text { Create interconnected } \\
\text { spaces with integrated }\end{array}$ \\
\hline
\end{tabular}




\begin{tabular}{|l|l|l|l|}
\hline & $\begin{array}{l}\text { encourages walkers to } \\
\text { move and watch where } \\
\text { they walk in. }\end{array}$ & space. & $\begin{array}{l}\text { spaces that may seem } \\
\text { safe. }\end{array}$ \\
\hline Elizabeth Wood & $\begin{array}{l}\text { Theory of physical } \\
\text { design in community. }\end{array}$ & $\begin{array}{l}\text { Managers of residential } \\
\text { areas can never lead to } \\
\text { destructive actions } \\
\text { done by careless } \\
\text { tenants and even a } \\
\text { small group of } \\
\text { dissidents. }\end{array}$ & $\begin{array}{l}\text { Create spaces so its } \\
\text { residents come together } \\
\text { to monitor residents. }\end{array}$ \\
\hline Angel & $\begin{array}{l}\text { Emphasizing the } \\
\text { importance of the } \\
\text { physical environment. }\end{array}$ & $\begin{array}{l}\text { Measures for citizens } \\
\text { and police surveillance } \\
\text { are done through } \\
\text { physical environment. }\end{array}$ & $\begin{array}{l}\text { By specifying the } \\
\text { limits ownership, } \\
\text { reduce or increase the } \\
\text { access to the site. }\end{array}$ \\
\hline
\end{tabular}

Reference: (Carmona et al., 2003:121)

\section{Geographical location of Chaloos}

Chaloos is located at north of Iran. At the 2006 census, its population was around fiftythousand. The average annual growth rate is $2.61 \%$. The table below shows the number and rate of population growth during 1956-2006 in Chaloos.

\section{Determining affluent and non-affluent neighborhoods in Chaloos}

Chaloos has 22 neighborhoods. To determine affluent and non-affluent neighborhoods 40 questionnaires were distributed to municipal experts, professors and students at Mazandaran University and residents of Chaloos. Average points were determined according to 1 to 5 point in two separated tables of affluent and non-affluent neighborhoods to determine areas. As a result, the two districts as the representative of affluent neighborhoods, respectively, with an average score of (3.20) and (2.15) were determined as the representatives of affluent neighborhoods the two districts as the representative of non-affluent neighborhoods, respectively, with an average score of (3.25) and (2.15) were determined as the 
representatives of non-affluent neighborhoods as the sample among the 22 neighborhoods of Chaloos.

\section{Analytical findings}

Criteria considered for evaluation of crime in affluent and non-affluent neighborhoods of Chaloos include: habitat quality, visual richness and diagnostics (symbol). Below we analyze these three criteria.

The study population consists of households' heads in the two districts as the representative of affluent neighborhoods (110) and two districts as the representatives of non-affluent neighborhoods (160) on behalf of all neighborhoods in Chaloos. Questions and statements of questionnaire were designed according to theoretical and operational definitions of variables and the relevant experts so that it has validity. Cronbach's alpha coefficient of the questionnaire was estimated to be 0.881 ; this value represents questionnaire's reliability.

Three components were used for determining the spatial differences criteria in Chaloos, including visual richness, habitat quality, diagnostics (symbol). To test this hypothesis, T-test was used to determine components.

\section{Habitat quality}

Abandoned and destroyed residential buildings, abandoned land and spaces and benches for adults' leisure time in the neighborhood are items that form the habitat quality criteria. In the affluent neighborhood, abandoned and destroyed residential buildings by (4.15) and abandoned land and spaces by (4.06) are higher than the average amount and 1 benches for adults' leisure time by (2.15) is lower than the average amount, while all three components of habitat quality are lower than the average in non-affluent neighborhoods.

Table 2: Statistical information of habitat quality components

\begin{tabular}{|c|l|c|c|c|c|}
\hline $\begin{array}{c}\text { Habitat quality } \\
\text { components }\end{array}$ & $\begin{array}{l}\text { Type of } \\
\text { neighborhood }\end{array}$ & $\mathrm{N}$ & Mean & $\begin{array}{c}\text { Std. } \\
\text { Deviation }\end{array}$ & $\begin{array}{c}\text { Std. Error } \\
\text { Mean }\end{array}$ \\
\hline Habitat quality & Affluent & 110 & 3.45 & .736 & .070 \\
\hline
\end{tabular}




\begin{tabular}{|c|l|c|c|c|c|}
\hline & Non-affluent & 160 & 1.92 & .660 & .052 \\
\hline $\begin{array}{c}\text { Abandoned and } \\
\text { destroyed residential } \\
\text { buildings }\end{array}$ & Affluent & 110 & 4.15 & .826 & .079 \\
\cline { 2 - 6 } & Non-affluent & 160 & 2.24 & .994 & .079 \\
\hline $\begin{array}{c}\text { Abandoned land and } \\
\text { spaces }\end{array}$ & Affluent & 110 & 4.06 & 1.206 & .115 \\
\cline { 2 - 7 } & Non-affluent & 160 & 2.34 & 1.082 & .086 \\
\hline \multirow{2}{*}{$\begin{array}{c}\text { Benches for adults' } \\
\text { leisure time }\end{array}$} & Affluent & 110 & 2.15 & 1.180 & .112 \\
\cline { 2 - 7 } & Non-affluent & 160 & 1.18 & .512 & .041 \\
\hline
\end{tabular}

Reference: Results obtained from questionnaires

\section{Visual richness}

Among four items related to visual richness in affluent neighborhood, three of them including buildings with dirty façade by (4.05), dirty and broken boards by (4.11) and abnormal graffiti by (3.45) are above the average, and relaxing and pleasant colors by (2.73) is less than the average; while all items of visual richness in non-affluent neighborhoods are moderately lower than average, the least is relaxing and pleasant colors by an average of (1.77).

Table 3: Statistical information of visual richness components

\begin{tabular}{|l|l|l|l|l|c|}
\hline \multicolumn{1}{|c|}{$\begin{array}{c}\text { Visual richness } \\
\text { components }\end{array}$} & \multicolumn{1}{c|}{$\begin{array}{c}\text { Type of } \\
\text { neighborhood }\end{array}$} & $\mathrm{N}$ & Mean & $\begin{array}{c}\text { Std. } \\
\text { Deviation }\end{array}$ & $\begin{array}{c}\text { Std. Error } \\
\text { Mean }\end{array}$ \\
\hline Visual richness & Affluent & 110 & 3.58 & .706 & .067 \\
\cline { 2 - 6 } & Non-affluent & 160 & 2.23 & .628 & .049 \\
\hline Buildings with dirty & Affluent & 110 & 4.05 & .985 & .094 \\
\hline
\end{tabular}




\begin{tabular}{|c|c|c|c|c|c|}
\hline $\begin{array}{l}\text { facade } \\
\text { Dirty and broken } \\
\text { boards }\end{array}$ & Non-affluent & 160 & 2.14 & 1.043 & .082 \\
\hline \multirow[t]{2}{*}{ Abnormal graffiti } & Affluent & 110 & 4.11 & 1.095 & .104 \\
\hline & Non-affluent & 160 & 2.58 & 1.113 & .088 \\
\hline \multirow{2}{*}{$\begin{array}{l}\text { Buildings with dirty } \\
\text { facade } \\
\text { Dirty and broken } \\
\text { boards }\end{array}$} & Affluent & 110 & 3.45 & 1.209 & .115 \\
\hline & Non-affluent & 160 & 2.44 & 1.091 & .086 \\
\hline \multirow[t]{2}{*}{ Abnormal graffiti } & Affluent & 110 & 2.73 & 1.149 & .110 \\
\hline & Non-affluent & 160 & 1.77 & .848 & .067 \\
\hline
\end{tabular}

Reference: Results obtained from questionnaires

\section{Diagnostics (symbol)}

Among the items of diagnostics (symbol); legibility of physical form in the neighborhood by (3.20) and the possibility of escape in case of danger by (3.53) are higher than the average in affluent neighborhoods and in non-affluent neighborhoods the possibility of escape in case of danger by (3.22) is higher than the average and legibility of physical form in the neighborhood by (2.41) is lower than the average.

Table 4: Statistical information of diagnostics (symbols) components

\begin{tabular}{|c|l|c|c|c|c|}
\hline Diagnostics & $\begin{array}{l}\text { Type of } \\
\text { neighborhood }\end{array}$ & $\mathrm{N}$ & Mean & $\begin{array}{c}\text { Std. } \\
\text { Deviation }\end{array}$ & $\begin{array}{c}\text { Std. Error } \\
\text { Mean }\end{array}$ \\
\hline Diagnostics & Affluent & 110 & 3.36 & .815 & .077 \\
& Non-affluent & 160 & 2.81 & .699 & .055 \\
\hline
\end{tabular}




\begin{tabular}{|c|l|c|c|c|c|}
\hline $\begin{array}{c}\text { Legibility of physical } \\
\text { form in the } \\
\text { neighborhood }\end{array}$ & Affluent & 110 & 3.20 & 1.132 & .108 \\
\cline { 2 - 6 } & Non-affluent & 160 & 2.41 & .857 & .068 \\
\hline $\begin{array}{c}\text { The possibility of } \\
\text { escape in case of } \\
\text { danger }\end{array}$ & Affluent & 110 & 3.53 & .864 & .082 \\
\cline { 2 - 6 } & Non-affluent & 160 & 3.22 & 1.160 & .092 \\
\hline
\end{tabular}

Reference: Results obtained from questionnaires

\section{Criteria quality assessment using one-sample t-test}

The following table, results of one-sample t test are shown for factors that reduce crime inducing culture.

In the affluent neighborhood of 3 factors including habitat quality, visual richness and diagnostics (symbol) with values equal to (3.4), (3.5) and (3.3) are higher than the average, as well as the significance level calculated in the alpha equal to (0.000), so it can be claimed that the criteria status in the specified neighborhood is in an appropriate level. But in non-affluent neighborhoods, it is opposite. Three components of habitat quality, visual richness and diagnostics (symbol) with values equal to (2.7), (2.9) and (2.8) are lower than the average.

Table 5: Results of one-sample t-test for each criteria of sustainability in the neighborhood

\begin{tabular}{|c|c|c|c|c|c|c|c|c|c|c|}
\hline 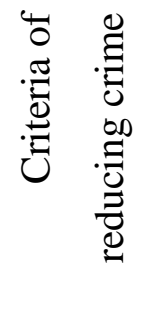 & 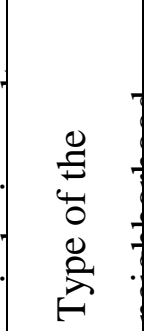 & 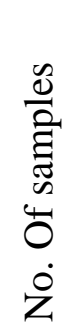 & 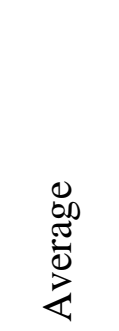 & 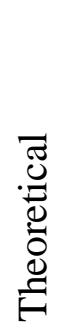 & 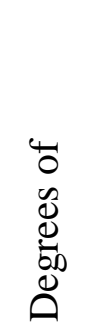 & $\begin{array}{l}\text { 营 } \\
\text { 营 }\end{array}$ & 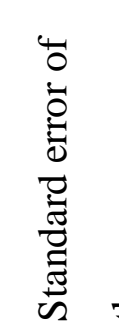 & 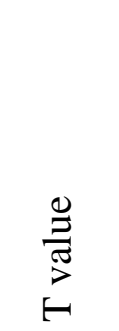 & 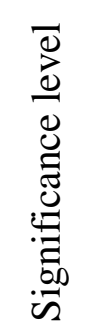 & 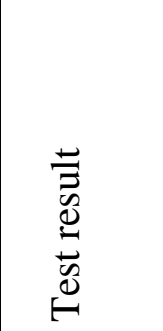 \\
\hline \multirow[t]{2}{*}{$\begin{array}{l}\text { Habitat } \\
\text { quality }\end{array}$} & Affluent & 110 & $\begin{array}{c}3.454 \\
5\end{array}$ & 3 & 109 & $\begin{array}{c}.7360 \\
4\end{array}$ & $\begin{array}{c}.0701 \\
8\end{array}$ & 6.477 & .000 & $\begin{array}{c}\mathrm{H} 0 \\
\text { rejected }\end{array}$ \\
\hline & Non- & 160 & 1.920 & 3 & 159 & .6608 & .0522 & - & .000 & HO \\
\hline
\end{tabular}




\begin{tabular}{|c|c|c|c|c|c|c|c|c|c|c|}
\hline & affluent & & 8 & & & 6 & 5 & $\begin{array}{c}20.65 \\
6\end{array}$ & & $\begin{array}{c}\text { confirm } \\
\text { ed }\end{array}$ \\
\hline \multirow[t]{2}{*}{$\begin{array}{l}\text { Visual } \\
\text { richness }\end{array}$} & Affluent & 110 & $\begin{array}{c}3.586 \\
4\end{array}$ & 3 & 109 & $\begin{array}{c}.7066 \\
5\end{array}$ & $\begin{array}{c}.0673 \\
8\end{array}$ & 8.703 & .000 & $\begin{array}{c}\mathrm{H} 0 \\
\text { rejected }\end{array}$ \\
\hline & $\begin{array}{c}\text { Non- } \\
\text { affluent }\end{array}$ & 160 & $\begin{array}{c}2.231 \\
2\end{array}$ & 3 & 159 & $\begin{array}{c}.6285 \\
6\end{array}$ & $\begin{array}{c}.0496 \\
9\end{array}$ & 15.47 & .000 & $\begin{array}{c}\text { H0 } \\
\text { confirm } \\
\text { ed }\end{array}$ \\
\hline \multirow{2}{*}{$\begin{array}{l}\text { Diagnosti } \\
\text { cs } \\
\text { (symbol) }\end{array}$} & Affluent & 110 & $\begin{array}{c}3.363 \\
6\end{array}$ & 3 & 109 & $\begin{array}{c}.8153 \\
0\end{array}$ & $\begin{array}{c}.0777 \\
4\end{array}$ & 4.678 & .000 & $\begin{array}{c}\mathrm{H} 0 \\
\text { rejected }\end{array}$ \\
\hline & $\begin{array}{c}\text { Non- } \\
\text { affluent }\end{array}$ & 160 & $\begin{array}{c}2.818 \\
8\end{array}$ & 3 & 159 & $\begin{array}{c}.6992 \\
5\end{array}$ & $\begin{array}{c}.0552 \\
8\end{array}$ & 3.279 & 1.00 & $\begin{array}{c}\text { H0 } \\
\text { confirm } \\
\text { ed }\end{array}$ \\
\hline
\end{tabular}

Reference: Results obtained from questionnaires

The correlation between the components and criteria

\section{Habitat quality and reduction in crime-inducing culture}

Pearson correlation coefficient between habitat quality and reduction in crime-inducing culture is shown in Table 6.

Table 6: Correlation between habitat quality and reduction in crime-inducing culture

\begin{tabular}{|c|c|c|c|}
\hline \multicolumn{3}{|c|}{ Correlation coefficient between habitat quality and reduction in crime-inducing culture in } \\
affluent neighborhood \\
\hline \multirow{2}{*}{ Habitat quality } & Pearson correlation & $\begin{array}{c}\text { Reduction in crime- } \\
\text { inducing culture }\end{array}$ & Habitat quality \\
\cline { 2 - 4 } & Sig. (2-tailed) & $.731^{* *}$ & 1 \\
\hline
\end{tabular}




\begin{tabular}{|c|c|c|c|}
\hline & $\mathrm{N}$ & 110 & 110 \\
\hline \multicolumn{4}{|c|}{ **. Correlation is significant at the 0.01 level (2-tailed). } \\
\hline \multicolumn{4}{|c|}{$\begin{array}{l}\text { Correlation coefficient between habitat quality and reduction in crime-inducing culture in } \\
\text { non-affluent neighborhood }\end{array}$} \\
\hline & & $\begin{array}{l}\text { Reduction in crime-inducing } \\
\text { culture }\end{array}$ & Habitat quality \\
\hline \multirow[t]{3}{*}{ Habitat quality } & $\begin{array}{c}\text { Pearson } \\
\text { correlation }\end{array}$ & $.594^{* *}$ & 1 \\
\hline & $\begin{array}{l}\text { Sig. (2- } \\
\text { tailed) }\end{array}$ & .000 & \\
\hline & $\mathrm{N}$ & 160 & 601 \\
\hline
\end{tabular}

Pearson correlation coefficients between these two variables in affluent and non-affluent neighborhoods are respectively 0.731 and 0.594 . And significant level in 0/05 alpha in both neighborhoods is $(0.000)$. Since the calculation error is less than 0.01 , with 99 percent confidence we can say that there is a direct and significant relationship between habitat quality and reduction in crime-inducing culture. In other words, as habitat quality increases in the two neighborhoods, there will be more reduction in crime-inducing culture.

\section{Visual richness and reduction in crime-inducing culture}

Pearson correlation coefficient between visual richness and reduction in crime-inducing culture is shown in Table 6.

Table 7: Correlation between visual richness and reduction in crime-inducing culture

Correlation coefficient between visual richness and reduction in crime-inducing culture in affluent neighborhood 


\begin{tabular}{|c|c|c|c|}
\hline Visual richness & $\begin{array}{l}\text { Reduction in crime- } \\
\text { inducing culture }\end{array}$ & & \\
\hline \multirow[t]{2}{*}{1} & $.738^{* *}$ & $\begin{array}{c}\text { Pearson } \\
\text { Correlation }\end{array}$ & \multirow[t]{3}{*}{ Visual richness } \\
\hline & .000 & Sig. (2-tailed) & \\
\hline 110 & 110 & $\mathrm{~N}$ & \\
\hline \multicolumn{4}{|c|}{ **. Correlation is significant at the 0.01 level (2-tailed). } \\
\hline \multicolumn{4}{|c|}{$\begin{array}{l}\text { Correlation coefficient between visual richness and reduction in crime-inducing culture in } \\
\text { non-affluent neighborhood }\end{array}$} \\
\hline Visual richness & $\begin{array}{l}\text { Reduction in crime- } \\
\text { inducing culture }\end{array}$ & & \\
\hline \multirow[t]{2}{*}{1} & $.667^{* *}$ & $\begin{array}{c}\text { Pearson } \\
\text { Correlation }\end{array}$ & \multirow[t]{3}{*}{ Visual richness } \\
\hline & .000 & Sig. (2-tailed) & \\
\hline 601 & 160 & $\mathrm{~N}$ & \\
\hline
\end{tabular}

Pearson correlation coefficients between these two variables in affluent and non-affluent neighborhoods are respectively 0.738 and 0.667 . And significant level in 0/05 alpha in both neighborhoods is (0.000). Since the calculation error is less than 0.01, with 99 percent confidence we can say that there is a direct and significant relationship between visual richness and reduction in crime-inducing culture. In other words, as visual richness increases in the two neighborhoods, there will be more reduction in crime-inducing culture. 


\section{Diagnostics (symbol) and reduction in crime-inducing culture}

Pearson correlation coefficient between diagnostics (symbol) and reduction in crime-inducing culture is shown in Table 6.

Table 8: Correlation between diagnostics (symbol) and reduction in crime-inducing culture

\begin{tabular}{|c|c|c|c|}
\hline \multicolumn{4}{|c|}{$\begin{array}{l}\text { Correlation coefficient between diagnostics (symbol) and reduction in crime-inducing } \\
\qquad \text { culture in affluent neighborhood }\end{array}$} \\
\hline Diagnostics (symbol) & $\begin{array}{l}\text { Reduction in crime- } \\
\text { inducing culture }\end{array}$ & & \\
\hline \multirow[t]{2}{*}{1} & $.550^{* *}$ & $\begin{array}{c}\text { Pearson } \\
\text { Correlation }\end{array}$ & \multirow[t]{3}{*}{ Diagnostics (symbol) } \\
\hline & .000 & Sig. (2-tailed) & \\
\hline 110 & 110 & $\mathrm{~N}$ & \\
\hline \multicolumn{4}{|c|}{ **. Correlation is significant at the 0.01 level (2-tailed). } \\
\hline \multicolumn{4}{|c|}{$\begin{array}{l}\text { Correlation coefficient between diagnostics (symbol) and reduction in crime-inducing culture } \\
\text { in non-affluent neighborhood }\end{array}$} \\
\hline Diagnostics (symbol) & $\begin{array}{l}\text { Reduction in crime- } \\
\text { inducing culture }\end{array}$ & & \\
\hline \multirow[t]{2}{*}{1} & .005 & $\begin{array}{c}\text { Pearson } \\
\text { Correlation }\end{array}$ & Diagnostics (symbol) \\
\hline & .949 & Sig. (2-tailed) & \\
\hline 601 & 160 & $\mathrm{~N}$ & \\
\hline
\end{tabular}

Pearson correlation coefficient between these two variables in affluent neighborhood is 0.550 . And significant level in $0 / 05$ alpha is (0.000). Since the calculation error is less than 0.01 , with 99 percent confidence we can say that there is a direct and significant relationship 
between diagnostics (symbol) and reduction in crime-inducing culture. In other words, as diagnostics (symbol) increases in the affluent neighborhood, there will be more reduction in crime-inducing culture. However in non-affluent neighborhood there is no significant relationship (0.949) between diagnostics (symbol) and reduction in crime-inducing culture.

\section{Conclusion}

According to Oscar Newman to create defensible space, each should have something in charge. Not user-defined areas (non-functioning) due to lack of applicability and being useless turn into abandoned spaces. And with the loss of their identity, they create the potential to be damaged. The results are consistent according to Oscar Newman; in component of habitat quality in affluent (0.731) and non-affluent (0.594) neighborhoods. Therefore, a space with something in charge reduces the vulnerability of neighborhoods and creates a sustainable environment for effective living.

Trancik says that part of urban spaces which are good visual proportions, in other words, where there is less visual disturbance are probably less associated with behavioral disturbances (abnormal behavior and anomic) than other parts (Trancik, 1986: 225). Visual disturbances in the city can be reflected on social behavior through the perceptions and justify abnormal behavior (behavioral disorders or anomic behavior) in urban space. (Lawson, 2006: 58). The results are in consistent with the findings of this study on the components of the visual richness of in both affluent (0.738) and non-affluent (0.667) neighborhoods. Therefore, there can be expressed visually desirable proportions in urban areas to reduce disturbances affect behavior.

Social pathology and deviations sociology studies showed that often people who have sense of disorientation for various reasons and have difficulties to recognize their position and direction are good prey for criminals (Lawson, 2006: 234). "A clear image of the environment, gives a sense of security to the person." (Lynch, 1967: 228). As a result, diagnostics (symbol) component in affluent neighborhoods (0.550) is in consistent with Lynch and Lawson views. But their theory is not confirmed in case of non-affluent neighborhoods. These results reflect the fact that in non-affluent neighborhoods people do not have a good diagnosis of symbol in their neighborhood. 


\section{Suggestions and strategies}

According to the analysis, findings and hypotheses and results, and to reduce crime-inducing culture in affluent and non-affluent neighborhoods and providing a secure environment in the city of Chaloos, suggestions and strategies to control and deal with crime-inducing culture in urban spaces are provided.

1. Improvement of physical constructions and lighting streets and alleys in non-affluent neighborhoods of Chaloos.

2. Change in the design of spaces without visual perspectives, especially in non-affluent neighborhoods of Chaloos.

3. Increase police and security centers in neighborhoods of Chaloos, to increase control in the neighborhoods.

4. Allocation and regulation of facilities and equipment and provide services that citizens need and provide balance and equality in the use and operation of municipal services between affluent and non-affluent neighborhoods of Chaloos.

5. Leading various society classes to participate in prevention and social security against crime is very useful.

\section{References:}

Abdollahi Haghi, M. (2004). Crime prevention through urban planning, case study of theft in the city of Zanjan. MSc Thesis, University of Zanjan.

Bayat, A. (2000). From 'Dangerous Classes' to 'Quiet Rebels': Politics of the Urban Subaltern in the Global South. International sociology, 15(3), 533-557.

Carmona, C., Heath, T., Oc, T. \& Tiesdell, S. (2003). Public Places and Urban Spaces: The Dimensions of Urban Design. London: Elsevier.

Cozens, P. M., Saville, G., \& Hillier, D. (2005). Crime prevention through environmental design (CPTED): a review and modern bibliography. Property management, 23(5), 328-356.

Crowe, T. D. (2000). Crime prevention through environmental design: Applications of architectural design and space management concepts. Butterworth-Heinemann. 
Dickens, C. (2004). Social reform and the empirical tradition in classic urban studies. Urban Theory and the Urban Experience: Encountering the City, 27.

Jacobs, J. (1961). The Death and Life of Great American Cities. New York: Vintage Books.

Lawson, B. (2006). How designers think: The design process demystified, (4 ${ }^{\text {th }}$ ed.). London: Elsevier.

Lynch, K. M. (1967). A Congreve gallery. London: Routledge.

Newman, G., Clarke, R. V. \& Shoham, S. G. (1997). Rational choice and situational crime prevention. Aldershot: Dartmouth.

Pierre Maurer, M. \& Allen, L. S. (1994). Urban spaces (design, implementation, management), translators: Hussein Rezai Mir Mojabi, Mohsen Rasuli. Tehran: Tehran Public and International Relations Department of Tehran Municipality.

Robinson, M. B. (2013). The theoretical development of "CPTED": Twenty-five years of responses to C. Ray Jeffery. The criminology of criminal law, 8: 427-462.

Salingaros, N. A. (1999). Urban space and its information field. Journal of Urban Design, 4(1), 29-49.

Trancik, R. (1986). Finding lost space: theories of urban design. John Wiley \& Sons. 